\title{
Az egészségturizmus folyamatainak terminológiai változásai
}

\author{
Szerzők: Zsarnóczky Martin ${ }^{1}$
}

Az egészségturizmus térhóditása és iparági növekedése évról évre elég dinamikusan fejlödik ahhoz, hogy az elmúlt évtizedek hazai tapasztalatait összegyüitve kiértékelésre kerülhessenek a fejlödési folyamatok. A korábbi periódusban a természeti tényezók nyújtotta lehetőségeken túlmenően a kiegészítő szolgáltatások is népszerübbé váltak. A folyamatokat vizsgálva mára megfigyelhetố, például a gyógyturizmuson belül, hogy a gyógyfürdôk legnagyobb profitú bevételi forrásai nem az önálló fürdôbelépó jegyek, hanem a hozzájuk kapcsolódó, de külön, helyben is igénybe vehetô, magas megtérülést hozó orvosi szolgáltatások, mint a plasztikai sebészet, a keringési betegségek gyógyászata, a szemészet, a meddőségi kezelések, illetve a professzionális fogászat. A külföldi vendégek számára megtévesztô lehet, ha egy szolgáltató a klasszikus szállodai wellness használatot (szauna, konditerem, medence) szolgáltatásként, orvosi jelenlétet is feltételezô egészségturisztikai csomagban értékesíti vagy kínálja eladásra. Tekintettel a kedvezô nemzetközi pozíció fenntartására, idôszerüvé vált, hogy a hazai egészségturizmusban érdekeltek közös terminológiai szabványosítást végezzenek, amelynek keretében a szolgáltatási csomagok helyes elnevezése további sikereket indukálhat a kiélezett versenyben.

Kulcsszavak: egészségturizmus, gyógyturizmus, wellness turizmus, terminológia.

\section{Bevezetés}

Jelenleg az egészséghez kapcsolódó nemzetközi gazdasági ágazatokban, a gyógyszerkutatások mellett az egészségturizmus az egyik legjobban fejlődő és finanszírozott iparág a világon. Az egészségügy innovációs költései dinamikusan nônek világszerte. A globális iparágak élvonalába tartozó, és a világ szinte minden szegletét átszövő turizmusnak vibráló célpontok, új tematikákkal feltûnő desztinációk versenyében kell tevékenykednie.

Napjainkban a kényes geopolitikai helyzetek megoldásának bizonytalansága és az újkori népvándorlás tömegei folyamatosan változó politikai környezetet hoztak létre, ami új megoldásokat követel az iparág szereplőitől, illetve gyors átrendezódéseket vált ki az egyes területeken. Az egészségturizmuson belül, a bizonytalanságot elkerülendő, a turizmus és az egészségügy meghatározó szereplői közös kapcsolódási pontokon szándékoznak - egymás erőforrásait tudatosan felhasználva - egy optimalizált méretû́ piacot kialakítani.

Az egészségturizmus kínálata egy állandóan fejlődő és rengeteg új lehetőséget magában foglaló turisztikai termékké vált. E változás folya-

\footnotetext{
${ }^{1}$ egyetemi adjunktus, Budapesti Corvinus Egyetem,

martin.zsarnoczky@uni-corvinus.hu
}

matainak megértése komplex ismereteket kíván. Az egészségturizmus népszerú termékeinek ismertetőjele és vonzereje az egészségmegőrzés, az egészségi állapot javítása és a jó közérzet elérése (MICHALKÓ 2012). Mivel az ilyen termékek piaca mind az egészségesek, mind az egészséges állapotot elérni kívánók számára különféle szolgáltatásokat nyújt, a hazai lakosság körében mára jól ismertté váltak az olyan kifejezések, mint a wellness, a prevenció, a terápia, a rehabilitáció és a fitnesz. A gyógyturizmus a gyógyulni kívánók számára kínál árban versengó szolgáltatásokat. A wellness turizmus pedig a jó testi kondíció fenntartását és a megelőzést célzó szolgáltatásokat nyújt.

Az elmúlt évtizedekben Magyarországon mindkét egészségturisztikai alszektor a jó adottságú és könnyen elérhető hazai gyógytényezôk, gyógyvizek vonzási köréhez kapcsolódott (ROBBINBRAD 2000, SMITH-PUCZKÓ 2010). A wellness turizmus rendszerében a szolgáltatók statisztikai adatbázisaiból kitûnik, hogy a lakosság szimpátiáját kiszolgáló élmény elemekkel társuló gyógyfürdőzés a szabadidő nagysikerú eltöltési módozatává vált. Nemzetközi összehasonlításban ettől eltérően, a régiónként és nemzeti kultúráktól függően egészen más húzó területek kapcsolhatóak össze az egészségturisztikai alszektorok jelentésével, fogalmainak tartalmával, mind a szolgáltatások típusai, mind a szolgáltatást igénybe vevők csoportjait tekintve (KINCSES 2011). 
Az iparági innováció hatására az egészségturizmus fogalomtára folyamatosan bővül, változásban van. Egyrészt bővül a szolgáltatási kínálat, hiszen új kreatív szolgáltatások és divatos trendek jelennek meg (MOLNÁR 2011), másrészrôl olyan új egészségügyi motivációk generálhatnak kiegészítő turisztikai alrendszereket, amelyeket a jövőben ismerhetünk csak meg.

Jelen pillanatban a hazai és a nemzetközi szakirodalom szerint is kétpólusú az egészségturizmus területe: a gyógyturizmusra és a wellness turizmusra osztható. A hazai szakemberek számára iránymutató Országos Egészségturizmus Fejlesztési Stratégia definíciója szerint: „Az egészségturizmus a gyógy- és wellness turizmust átfogó fogalom, a turizmusnak azon területét jelenti, ahol a turista utazásának fó motivációja az egészségi állapotának javítása és/vagy megőrzése, tehát a gyógyulás és/vagy a megelőzés, és ennek megfelelően a célterületen ${ }^{2}$ tartózkodása alatt igénybe is vesz egészségturisztikai szolgáltatás(oka)t." (AQUAPROFIT 2007).

Az egészségturizmuson belül kiemelt gyógyturizmus hazánkban olyan természeti tényezőkre épít, amelyek az emberi szervezetre gyógyhatással bírnak. Ilyen természeti gyógytényezők lehetnek a gyógyvizek, a gyógybarlangok, a gyógyiszap, a mofetta és a magaslati mikroklíma. Ezeket a szolgáltatásokat a gyógyulni vágyó betegek veszik igénybe, akik orvosi beutalóval és/vagy térítés ellenében igényelhetik. Az orvosi szolgáltatások mellé turisztikai kiegészítő csomagok párosíthatók, de minden esetben a gyógyító tevékenységen van a hangsúly. A gyógyhelyszínek kialakulásakor viszonylag rövid idôn belül megszületett a kúra (termékcsomag), mint egészségturisztikai szolgáltatás fogalma. Az európai kultúrkörben régi hagyományai vannak a gyógyvízre épülő és a természeti tényezőket használó kúráknak, amelyek ma orvosi felügyelet mellett, balneoterápiás és fizioterápiás kezelésként alkotják a terméket vagy szolgáltatást. Ezek a kezelések manapság inkább a terápiának megfelelő tartalommal bírnak.

Érdekes szakmai elgondolás volt egy évtizede, hogy a terápiás vagy gyógyászati turizmus elnevezést a MAGYAR TURIZMUS ZRT. (2008) minden szereplőtől különálló turisztikai irányként népszerûsítette a gyógyturizmuson belül. Ebben az elképzelésben, a professzionális turizmustól távol álló módon, csekély szerepük volt a turisztikai desztinációknak. A Magyar Turizmus Zrt. döntéshozóinak elgondolása szerint a termékeknek inkább az egyes állami vagy magánszolgáltatók szolgáltatási

\footnotetext{
${ }^{2}$ A 2016-os Turizmusfejlesztési Törvény szövegében ugyanez a korábbi célterület értelmezés már célhelyszín és/vagy desztinációként került átnevezésre.
}

helyéhez kellene kötődniük. Így a szolgáltatási helyek lehetnének állami kórházak vagy egészségügyi magánszolgáltatók is. A különféle szolgáltatókhoz köthetô egészségturisztikai szolgáltatási termékek kialakítása problémát jelentett, mert az akkori jogszabályok szerint a hagyományos orvosi, a nagy bevétellel rendelkező mútéti vagy klinikai, eljárásokat döntő többségében az állami szolgáltatók végezték volna. Az elképzelés szerint a magánszféra számára az alternatív gyógyításban lett volna nagyobb piaci tér. Ezek a tervek később "felpuhultak", és - a meglévő belföldi kereslethez kapcsolódva - a frissen létrehozott európai uniós pályázati finanszírozású magánklinikákon rohamtempóban kezdtek el terjedni a szépészeti, a plasztikai, a fogászati és a kozmetológiai beavatkozások.

\section{Elméleti háttér}

Az elmúlt évtizedekben a világméretú egészségturisztikai iparban, és ezzel párhuzamosan a helyi egészségturizmusban is használt fogalomtár jelentôs fejlődésen ment keresztül. A turizmus összetettsége és megfelelően múködtetett rendszere miatt egyáltalán nem vehető bizonyosra, hogy ugyanaz a fogalomrendszer különféle behatások vagy érdekek érvényesülése után is uniformizált tartalommal rendelkezik. Az egészségturizmusban ugyanúgy, mint a turizmus egészében, az élményszerzés ígérete és a motiváció felkeltése fontos feladat az iparági szakemberek számára.

$\mathrm{Az}$ árérzékeny turisztikai termékek, csomag kialakítások is megváltoztak, és sok esetben már nem kizárólag a keresleti szempontok, hanem a kínálati döntéshozók preferenciái mozgatják azokat. A kínálatot a korábbi években jellemzó silány vagy alacsonyabb értékú szolgáltatási tartalom mára inkább valamilyen preferenciát megtestesíto célban nyilvánul meg. Ilyen lehet például a magas foglaltság generálása vagy a keresleti összetétel változtatásának szükségessége. Az egészségturizmusban - ellentétben a tágabban értelmezett turisztikai szolgáltatások sokszínúségével - fontossá vált, hogy a kínált termék, szolgáltatás vagy az adott desztináció marketingstratégiája világos és egyszerúen megérthetô jelzést adjon a vásárlói döntéshez.

$\mathrm{Az}$ egészségturizmus sajátossága a nevében is benne rejlő egészség szó, amely a turizmus keretein belül ugyan a szabadidő eltöltésére szolgál, túlnyomó többségében pihenő, rekreációs és gyógyító szolgáltatásokat kínál. Az egészségturizmus felfutásában közremúködő különféle szakértők és szakemberek az egyes tudományterületeken felhalmozott tapasztalataik átadásával nagyban hozzájárultak a hazai induláshoz amikor széleskörúen 
Lektorált tanulmányok

értelmezhetô jelentésekkel ruházták fel az egészségturisztikai fogalomrendszert, mégsem tudtak minden érdekelt résztvevő számára egységes keretet alkotni. A jogalkotói képviselet, az egészségügy, a sporttudomány, a turizmus, valamint a szakmai érdekképviseletek szereplői egy önálló hazai fogalmi értelmezésben és nem a rendelkezésre álló nemzetközi sztenderdek által megfogalmazott keretrendszer alkalmazásában voltak érdekeltek (1. ábra). A hazai adottságokon és az OsztrákMagyar Monarchia korabeli hagyományain alapuló tapasztalatok jelentették az akkor elkészült munka alapjait (ZSARNÓCZKY 2017a).

1. ábra

A hazai egészségturizmus kialakításában részt vevó szereplók

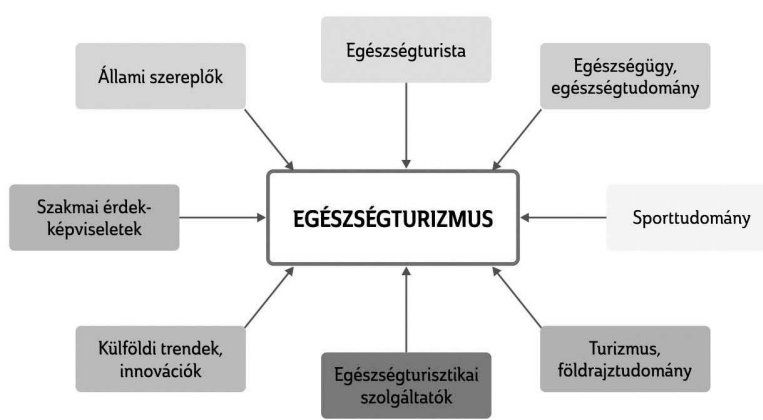

Forrás: saját szerkesztés, saját kutatás alapján

A 2000-es Nemzeti Fejlesztési Stratégia keretében végzett munka eredménye a gyógyturizmus alrendszerének - nemzetközi összehasonlításban is kiválónak mondható - szakmai kidolgozása, amelyben a hazai gyógytényezókre alapozott gyógyturisztikai alrendszer túlpozícionálttá vált. Az 1970-es években az ENSZ által elkészíttetett és a hazai termálvíz adottságokat figyelembe vevő fejlesztési elképzelések magukban foglalták a századfordulón létesült üdülóhelyek hagyományait, valamint az éppen aktuális területfejlesztési koncepciókat is. Az ezredfordulón ezeken az információkon nyugvó elképzelésként fejlődött tovább a természeti erőforrásokra, döntően a termálvizekre alapozott hazai egészségturizmus fejlesztési koncepció. Ennek önmagában semmilyen negatív következménye nem lett, sőt sok esetben olyan forrásokat biztosított az akkori célokhoz, amelyek nélkül ma Magyarország nem lehetne a piacvezetók egyike ezen a területen. Viszont nem lett sokkal átláthatóbb azóta sem, hogy a hazai egészségturizmust a területfejlesztés, az egészségügy vagy a turizmus jogviszony rendszerében kell-e értelmezni. Ez azért jelent problémát a jövőre nézve, mert jelenleg mind a területfejlesztés területe, mind az egészségügy egésze törvényileg szabályozott, ezáltal adminisztratívan múködtethetô, ezzel ellentétben a turizmus jogi hátterének kidolgozása nagyon lassú ütemben halad.

A turisztikai szakemberek számára az egészségturizmus típusok elméleti összefoglaló ábráját a SMITH-PUCZKÓ (2010) szerzőpáros készítette el, amely azóta is irányadó a hazai gyakorlatban. A 2. ábrán a turizmus szempontjából konszenzusos formában kerültek meghatározásra a célok és a fejlesztendó területek. Ezen kívül készültek még egészségturizmus típusokat összefoglaló táblázatok, amelyek az érintett tudomány-szakterületek értelmezési különbségéból adódóan különböznek.

2. ábra

\section{Az egészségturizmus összefoglaló ábrája}

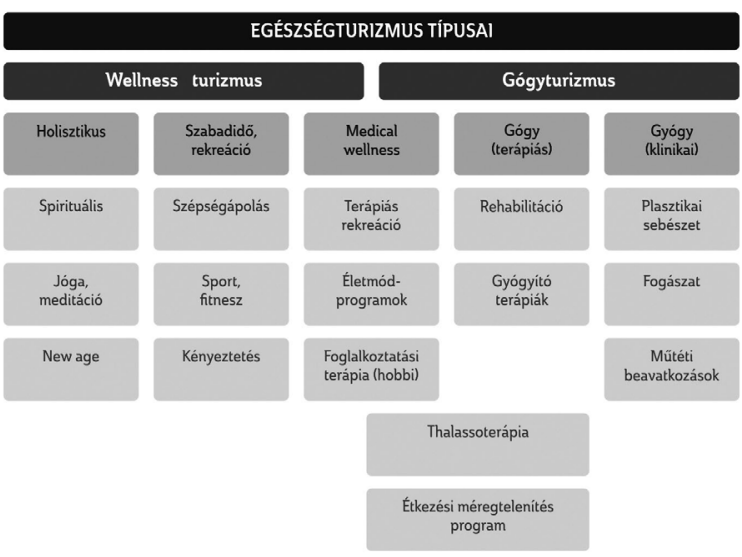

Forrás: SMITH-PUCZKÓ (2010:24)

Alapjában véve az egészségturizmus két területére más típusú motivációval rendelkezó keresleti szegmens a jellemzô, amelyek egyáltalán nem zárják ki egymást, sôt ilyen irányú igény esetén kombinálhatók is. A gyógyturizmus során a motiváció valamilyen gyógytényezóhöz vagy a gyógyuláshoz, míg a wellness turizmus esetén az egészségturisztikai élményhez kötött. Érdekesség, hogy korábban létezett az „egészségügyi turizmus" (NGM 2010) fogalma, amely többféleképpen értelmezhetó módon az egészségügyi - valószínúsíthetően orvosi - szolgáltatás igénybevételéhez kötötte a turisztikai motivációt. A 2015-ben megszüntetésre került, de az akkori koncepcióban még aktívan résztvevő Gyógyszerészeti és Egészségügyi Minőség- és Szervezetfejlesztési Intézet (GYEMSZI) szintén létrehozta a saját fogalomrendszerét, amelyben wellness turizmus helyett a "prevenciós és rekreációs turizmus" elnevezést javasolta, aminek motivációja az egészség fejlesztésének igénye volt (ZSARNÓCZKY 2015). 


\section{Módszer}

Jelen kutatásban összegyújtésre kerültek az egészségturizmus megértését elősegítő fogalmak, terminológiák, amelyek egy része az elmúlt évtizedekben sem tudott minden szempontból megnyugtatóan kikristályosodni. Ebből az okból kifolyólag, az egészségturizmus folyamatait komplexen érdemes vizsgálni. A rövidtávon változó tulajdonosi, döntéshozói érdekeknek megfelelően összeállított hazai kínálat változásban van, aminek következtében a saját marketingkommunikációjában a felismerhető, világosan leírt élményt és vonzerôt felmutató termékek tudják magukat (jobbára) értékesíteni a turisztikai desztinációkban (HORKAY 2003). Ettől függetlenül az egészségturizmuson belül sem a nemzetközi, sem a hazai szakmai fogalomtárak nem gyưjtik és jelzik az esetleges terminológiai eltéréseket, fejlődéseket.

A kutatói hipotézis alapján eltérô terminológiai használat és fogalomtársítás van használatban a különféle szereplók között. A keresleti szegmens számára szükségszerúvé vált az a fajta tudatos vásárlói magatartás gyakorlata, aminek keretében az egyes iparágakhoz köthetô és csupán arra jellemző fogalmi megközelítéseket egy nemzetközileg elfogadott fogalomrendszerben lehetne az egységesen elfogadott tartalmuk alapján értelmezni.

Sajnálatos módon hazánkban kevésbé állnak rendelkezésre olyan szekunder források vagy adatbázisok, amelyekből hiteles adatok gyújthetôk az egészségturizmus teljes területét kutatók számára, ezért primer kutatásként a népszerú belföldi wellness turizmus kapcsán készült terminológiai vizsgálat. A vizsgálat elsô részében 150 turista kérdőíves lekérdezése történt meg, amiból a 82 darab hibátlanul felvett kérdőív eredménye kerül bemutatásra. A második kutatási munkarészben az egészségturizmusban tevékenykedő egészségügyi (orvos) és döntéshozó szakemberek (22 fő) mélyinterjúi és véleményei kerültek elemzésre. A félig strukturált interjúk során a szakembereknek lehetôségük volt, hogy a nyitott kérdések kapcsán szabadon osszák meg egyéni gondolataikat, melyek jelentôs része beépíthetố volt a kutatási eredmények közé. Két független csoport terminológiai vizsgálatának eredményei kerültek összevetésre és bemutatásra a munkában, viszont ezek az adatok a kis mintaszám miatt nem vehetôk általános érvényúnek. A megállapítások olyan pillanatfelvételek, amelyek további kutatási kérdéseket, irányokat indukálhatnak a témával foglalkozó kollégák számára.

\section{Eredmények}

A nemzetközi szakirodalom fogalmait tekintve a hazai terminológia és az ahhoz tartozó szakmai elnevezések több esetben nem mutatnak egyezést. Az egészségturizmus összetett és fejlődés alatt áll, ezért nemzetközileg elfogadott definíciókkal nem rendelkezik (RULLE-BRITTNER 2011). Az egészségturizmus a gyógy-, a prevenciós- és a rekreáció-turizmust foglalja magában, ahol a motiváció az egészségi állapot javítása és/vagy megőrzése, illetve a gyógyulás és/vagy a betegség megelőzése. Ennek érdekében a desztinációkban vagy a célhelyszínen való tartózkodás alatt a turisták egészségturisztikai szolgáltatásokat vesznek igénybe (CASSENS et al. 2012). Az egészségturizmus folyamatában a turisták általi kereslet lokális helyett globális szinten találkozott az orvosi szolgáltatások kínálatával (BOOKMAN et al. 2007).

Európa angolszász területein a népszerú és hagyományokkal rendelkező SPA elnevezéssel múködő intézmények biztosítják az egészségturisztikai szolgáltatások nagyobb részét. Ezekben az intézményekben a SPA elnevezéshez (salus per aquam - vízból nyert egészség) valamilyen típusú gyógy- vagy termálvíz köthetô a térségben vagy a településen. A SPA fogalom használatát fokozatosan átvették a közelben található hotelek, ahol ezekhez a vizekhez köthetố és más kiegészítô szolgáltatások voltak elérhetóek. Angol nyelvterületen a terminológiában az ezredforduló előtt döntően a medical tourism és a medicinal tourism elnevezések fedték le az egészségturizmus tevékenységét. Ezek a terminológiák tovább bővültek, és amit ma health tourism elnevezéssel szolgáltatásként kínálnak, az valójában a wellness tourism szinonimájához hasonlatos.

$\mathrm{Az}$ angol medical tourism kifejezésben a medical szó nem állítható párhuzamba a magyarországi gyógyvizekre alapozott gyógyturizmus fogalmával. A medical tourism során a turista mindenképpen valamilyen orvosi szolgáltatást vesz igénybe, és állandó lakhelyét ennek okán elhagyja. A medicinal tourism keretében inkább valamilyen gyógytényező miatt teszi ugyanezt. A medical tourism és a medicinal tourism orvosi beavatkozást, kezelést, gyógytényező igénybevételét foglal(hat)ja magában, míg a health tourism és a wellness tourism többnyire egészségjavító, egészségfenntartó szerepet tölt be.

$\mathrm{Az}$ angolszász közös gyökereknek köszönhetôen az észak-amerikai kontinensen kialakult egy önálló fogalmi kategória az eredeti SPA elnevezésból, az úgynevezett daily spa, amely szépészeti és kisebb kozmetológiai szolgáltatásokat nyújt az érdeklődő́k számára. A daily spa szolgáltatásainak 
Lektorált tanulmányok

már semmilyen kapcsolata nincs a salus per aquam eredeti jelentésével. A következő fejlődési fokot a SPA desztinációk létrejötte jelentette, amelyek felsô kategóriás, orvosi felügyelettel is ellátott helyszínek, célterületek. Az elsóként létrejött SPA desztinációk a karibi régióban és Ázsia turisztikailag gyorsan fejlődő területein találhatóak. Ezeken a helyeken és régiókban viszont egyáltalán nem honosodtak meg a tevékenységükhöz szorosan köthető korábbi terminológiai kifejezések, mint a SPA tourism vagy a selfness tourism ${ }^{3}$.

A volt Osztrák-Magyar Monarchia területén kialakult korabeli üdülőhelyeken a termál-, ásvány- és forrásvíz (thermal, mineral, spring water) szakkifejezések mind a mai napig jelen vannak az egészségturizmus gyakorlati szóhasználatában, amely ennek a földrajzi régiónak a sajátossága. A Monarchia sok hagyománnyal gyarapította a mai egészségturizmust a kelet-közép-európai régióban, Németországban viszont más típusú fejlődés ment végbe. A főbb német szakmai nyelvterületeken az egészségturizmus a Gesundheitstourismus kifejezéssel köthetó össze. A német nyelvben a Gesundheitstourismus a hagyományokkal rendelkezó kúra, terápiás vagy gyógyászati tevékenységgel összefüggő tágabb elnevezés. A német egészségturizmus gyakorlatában a kúra igénybevétele orvosi ajánlásra történik, és finanszírozott gyógykezelés társul hozzá.

A minél pontosabb tartalmi meghatározások megértése érdekében szükséges tisztázni, hogy a hazai koncepció kidolgozásakor az egészségturisztikai szakemberek számára a tudományos-technikai megközelítés képezte a fogalmak, a szóhasználat alapját. Csak a megfelelő tartalmú szóalkotás, fogalomképzés vagy a fogalmak legjellemzőbb tulajdonságainak leírása után lehet terminusokat képezni (FÓRIS 2005). A terminus egy olyan szakterülethez tartozó kifejezés (KIS 2005), amely ha nincs precízen pontosítva, akkor folyamatosan változhat. A világ turizmusában éppen kommunikációs forradalom zajlik, amelynek következtében a turista a globális márkajelzések, útmutató táblák, piktogramok és nemzetközileg elfogadott védjegyek alapján tájékozódik. Ezen a versengó piacon kizárólag az értékesító és marketing szakemberek döntése, hogy az egészségturisztikai szolgáltatásokat milyen elnevezéssel értékesítik. Sajnálatos módon sok esetben ezek a "becsomagolt” gyógyító ajánlatok nem egyeznek meg a szakmailag elvárt tartalommal. Az eltérések alapján megállapítható, hogy az egyes területek szakemberei közti kommunikáció, a földrajzi szóhasználat, valamint a szakmai terminológia nincs egyértelmúen közvetítve felhasználók felé.

\footnotetext{
${ }^{3}$ Komplex egészségtudatra fókuszáló turizmus típus, amelyben önmagunk
} megtalálása a fö cél.
A kutatási eredmények szempontjából érdekes a wellness turizmus - amelyhez egyébként nagyon népszerú belföldi turisztikai motiváció köthetó hazánkban - szaknyelvének átalakulása. A külföldi szakirodalom nagyjából megegyezik a hazai szakkönyvekkel, azzal a különbséggel, hogy külföldön a fogalomba a testi-lelki harmónia megteremtéséhez szükségesnek vélt mentális jóllét, valamint a wellness tevékenység által biztosítható rendszeres fizikai mozgás fenntartása is beletartozik. Az egészséges életmód tudatos fenntartásában az életminőség és az emberi felelősség is komoly szerepet játszik (ARDELL 1977). Az ARDELL wellness modelljében kialakított 5 elemnek az egyén szempontjából tulajdonítottak fontosságot, és a későbbi átdolgozások során mindvégig a boldogság utáni vágy maradt az egyik fó motiváció (HERMES 2005). A hazai wellness szakemberek nem taglalták a boldogság utáni vágy vagy az egyéni felelősség témakörét. A különféle hazai szakmai definíciókat összefoglalva a wellness lényege a test és a lélek harmóniájának megfelelő egyensúlya, a mentális és fizikai jó(l)lét megteremtése, valamint egy egészséges életmód kialakítása. Természetesen a wellness állapot elérése után szükséges lenne a kialakított wellness életmód életstílusszerú fenntartása is, amiben fôleg az életminőség emelésén van a hangsúly. Továbbgondolva ezt a wellness állapotot, a fogalom úgy is értelmezhetô, hogy több, egymásra ható és összefüggó állapot harmonikus egyensúlyba hozása a végső́ cél.

Az elmúlt évszázadban az állami szerepvállalással támogatott, egészséges életmódra ösztönző tömegsportok, néhány kivétellel, elvesztették ilyen típusú közfunkciójukat. A globalizáció következtében az eltérô kultúrák összehasonlításával szinte az egész világon lehetôség nyílt más típusú és sokszínú szabadidős célú sporttevékenységek megismerésére. Ennek hatására megjelentek azok a vállalkozások, melyek elsôként kínáltak egyénre szabott szolgáltatások keretében, üzleti céllal egészségmegőrző koncepciókat. Ennek a folyamatnak a hatására az egészséges életmód felértékelése megteremtette a wellness szolgáltatások és termékek iránti igényt (FRIEDL 2007).

Magyarországon az egészség, az egészségtudatosság, illetve az egészségturizmus nem az aktív sportból kerül levezetésre, hanem a rendszeres testmozgás, a szabadidő és a rekreáció kombinációjából. Erre az egészségtudatos kombinációra épült rá az életminőség javításának lehetôsége. $\mathrm{Az}$ egészséges életmód és az életminőség szoros kapcsolatban áll egymással (MICHALKÖ-RÁTZ 2011). Az egészségturizmus keretében az egészségtudatos turisztikai fogyasztó a céltudatos és rendszeres testmozgással, az egészséges táplál- 
kozással, a pihenéssel és a szabadidő minőségi kihasználásával járul hozzá a betegségek megelőzéséhez és egészségének tudatos megőrzéséhez. A wellness magyarországi kialakulása a gyógyturisztikai fejlesztésekhez köthető, és a szakemberek tudatos törekvéseinek köszönhetó. A II. Nemzeti Fejlesztési Terv fejlesztési fejezeteiben a wellness fogalmát az egészségtudatossággal kapcsolták öszsze, de szabályozási tartalmat nem fúztek hozzá. Ebból adódóan az egy évtized alatt összeállított és múködtetett rendszerben minden érintett résztvevő hozzáadott vagy elvett a wellness fogalmából (FÓRIS-BÉRCES 2006). Az életmódként társított wellness sikere idehaza annak köszönhető, hogy hétköznapi értelmezése meglehetôsen sokrétú.

A szakemberek szerint a wellness turizmus sikere részben annak az idealizált feltételezésnek köszönhetô, hogy a turisták a szabadidejük eltöltése során kikapcsolódnak, élményeket szereznek, és a testmozgás révén javul mentális, fizikai és biológiai állapotuk. A wellness turizmus kínálatának köszönhetóen az egészséges és a beteg turisták egyaránt részesülhetnek a hagyományos és az alternatív gyógymódokból, amelyek sikeres alkalmazása során a mindennapi életmódba is bekerülhet ez a fajta „terápia”. A wellness tevékenység kínálatában lehetnek más terápiás csomagok is. A német egészségturizmusban a wellness turizmus kiegészül a Medical Wellness Tourismus típussal és az egészségmegőrzéssel kapcsolatos nyaralással. A Német Wellness Szövetség vezetője, LUTZ HERTEL (1992) szerint a wellness turizmus és az általa 1992-ben megalkotott Medical Wellness tevékenység jól megkülönböztethető, mert a wellness turizmus területén csak a Medical Wellness biztosít kontrolált orvosi felügyeletet és orvosi szolgáltatásokat. A medical wellness hazánkban egy viszonylag új egészségturisztikai területet jelent. A medical wellness folyamata során az elôzetes állapotfelmérés után, orvosi felügyelettel és háttérrel, a felek közösen dolgoznak ki egy szinergikus életmód koncepciót, amelyben a wellness jólléti szolgáltatásai mellett aktív sport és rehabilitációs elemek is lehetnek. Amennyiben egészségturisztikai hagyományainkat és annak történetét elemezzük, akkor a német megközelítésú Medical Wellness egy szanatóriumi koncepciónak az újragondolása, amelyben a szépségipar, az egészségügy, a turizmus és a sporttudományok együttesen vesznek részt. A Medical Wellness terjedése jelen pillanatban szolgáltatókhoz, célterületekhez kötött, ezért nagyon nehéz gyakorlati különbséget tenni abban, hogy a gyógyszálló vagy a gyógy-wellness hotel kínálatában mik a típusbeli különbségek. A Medical Wellnessre szakosodott intézmények szabadabban tudnák képviselni a természetgyógyászat kínál- ta lehetôségeket vagy az alternatív gyógymódok használatát. A Medical Wellness gyógyászati tevékenysége során előtérbe kerülhet a spiritualitás, a test, a szellem és a lélek egysége, amelyet jól kiegészíthetnek az egészségtudattal együtt járó szépség iránti törekvések.

$\mathrm{Az}$ egészségtudatos életmódon belül jól prognosztizálhatóan, trendszerúen zajlik az állandó kereslet élénkülés a lélekgyógyászati lehetóségek iránt, ezért a spirituális, a New Age $e^{4}$ a holisztikus és a jógához köthetố turisztikai ágak után érdeklődôk számára mindig lehet új a nap alatt. A távol-keleti természetgyógyászati módok és a holisztikus wellness divatszerúen, fokozatos népszerúség növekedéssel fognak teret hódítani az egész nyugati világban.

A terminológiai vizsgálathoz kapcsolódóan a turisták számára készített, a wellness jelentését tisztázni szándékozó kérdôíves kutatásból kiderült, hogy a hétköznapi nyelvhasználatban az egészségturisztikai fogyasztók nagyon szerteágazó fogalmakkal ruházzák fel a wellness jelentését. A kapott eredményekből kitúnik (3. ábra), hogy a wellness fogalmához tartozó 3 legfóbb leíró jelentés sokszínú tartalommal párosul a turistáknál. A kérdőívvel megkérdezettek többsége a valódi wellness jelentéséhez közel álló Mozgás, Sport, Egészség szavakat gondolta a legmegfelelőbbnek. A kérdốvekben a turisták által megadott szavak között található szélsőség, például az OKJ képzés és az all you can eat/svédasztalos büfé, amelyek távolról közelítik meg az egészségturisztikai szakma által elvárt tartalmat.

Wellnesshez társított fogalmak a turisták (balra) és a szakemberek (jobbra) részéról

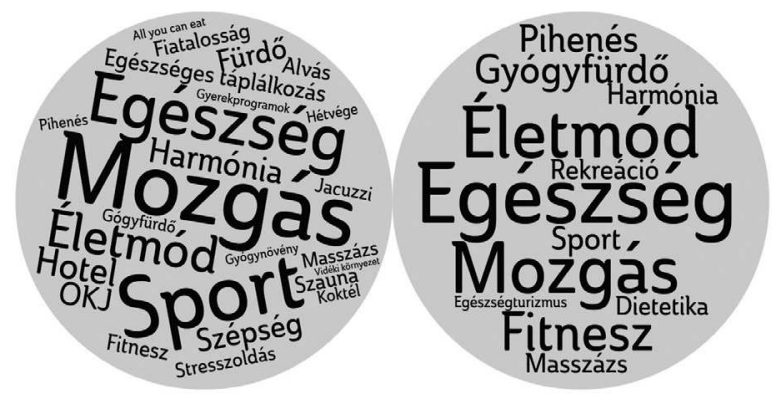

Forrás: saját szerkesztés a kérdőives kutatás alapján

Az egészségturizmusban tevékenykedó szakemberek, vezetők számára is készült egy, a wellness fogalmi jelentésére vonatkozó kutatási kérdőív a mélyinterjúk alkalmával. A kapott eredmények

${ }^{4}$ A relax turizmus egy jóval tágabban értelmezett formája, amelynek vallási elemei is lehetnek (VASILEIOU et al. 2016). 
Lektorált tanulmányok

jóval szofisztikáltabbak lettek (3. ábra), mint az előző, a turisták által megjelölt válaszokból leszúrtek. A wellnesst definiáló 3 leíró szó nem annyira sokrétú, mint a turistáknál készült vizsgálatnál, tehát a szakemberek számára jóval tisztább a kép. A megkérdezett 20 szakember csupán 12 különféle választ adott, amelyek közelebb állnak a hazai szakirodalmi terminológiához.

1. táblázat

Wellnesshez társított fogalmak összehasonlítása

\begin{tabular}{|c|c|c|}
\hline Helyezés & Turisták & Szakemberek \\
\hline 1. & Mozgás & Egészség \\
\hline 2. & Sport & Mozgás \\
\hline 3. & Egészség & Életmód \\
\hline 4. & Életmód & Fitnesz \\
\hline 5. & Hotel & Gyógyfürdő \\
\hline 6. & OKJ & Pihenés \\
\hline 7. & Harmónia & Sport \\
\hline 8. & Fürdó & Rekreáció \\
\hline 9. & Szépség & Dietetika \\
\hline 10. & Jakuzzi & Masszázs \\
\hline
\end{tabular}

Forrás: saját szerkesztés a 3. ábra alapján

Az 1. táblázatban a wellness szó fogalmi, tartalmi leírásával kapcsolatos két kutatási kérdőív eredménye került összehasonlításra. A táblázatban jól látható, hogy a wellness fogalmához kapcsolódóan mindössze a Mozgás, az Egészség, az Eletmód és a Sport szavak jelennek meg mindkét csoport esetében. A vizsgálat szempontjából a táblázat elsô helyein elhelyezkedó szavak megfelelő arányúnak számítanak és egyértelmú tartalommal bírnak. A közös szavak közel állnak a wellness turizmusban foglaltakhoz, de a maradék hat szót tekintve teljes fogalomhasználati eltérés tapasztalható. A turisták a további meghatározásokat illetôen nem az egészségturizmus terminológiai jelentéseit, hanem a rendelkezésre álló szolgáltatói kínálat specifikumait foglalták össze. Szerencsére a szakemberek megmaradtak az egészségturizmushoz közel álló fogalmaknál. Hétköznapi jelentésüket tekintve a szakemberek és a turisták szóhasználata merőben eltér egymástól, de eltéró tartalmúak a wellness tevékenységtől is. A kérdőívek adatai szerint a turisták $60 \%$-a az egészségturizmus tartalmától eltérôen használja a wellness fogalmát.

A wellnesshez kapcsolódó nemzetközi szakirodalomban a wellness életvitel a tudatos életmódhoz, az egészség karbantartásához, a helyes táplálkozáshoz és a pozitív életvitelhez szükséges értékek pozitív asszociációjához kapcsolódik, amelynek része a valamilyen rendszerességgel gyakorolt mozgás. Az eltérô hazai eredményekből jól látható, hogy a terminusok pontosított használata elengedhetetlenné vált az egészségturizmusban résztvevő́k számára. A fogalomképzés, amellyel egy adott jelenség legjellemzóbb tulajdonságait lehet leírni, jelenleg nem ugyanazon dolgokat jelenti a szakemberek és a turisták számára. Abban az esetben, ha az egészségturizmusban érintett területek szakemberei és a további érintett résztvevők közti kommunikáció, valamint a szakmai terminológusok jelentései nem precízek, illetve nem biztosítanak egyértelmú fogalomtársítást, a kommunikáció során a párosított tartalom folyamatosan változni fog.

\section{Következtetések}

Magyarországon az egészségturizmus múködési területe a gyógy- és wellness turizmust foglalja magába. Az egészségturizmus idehaza a természetes (gyógy)tényezókre épít, amelyek gyógyhatással vannak az emberi szervezetre, és megfeleló mennyiségben állnak rendelkezésre. Az egészségturisztikai szolgáltatások bizonyos részeit a gyógyulni vágyók orvosi kontroll mellett, térítés ellenében vehetik igénybe. Az állami tulajdonban lévő egészségturisztikai szolgáltatók rendelkeznek ugyan bizonyos szúkös kínálattal, de ugyanazon egészségügyi infrastruktúra többcélú felhasználása már problémákat vethet fel.

Hazánkban az egészségtudatossággal is párosuló egészségturizmust nem az aktív sport tevékenységből, hanem a rendszeres testmozgás, a szabadidô és a rekreáció kombinációjából alakította ki mára a piac. Fontos kiemelni, hogy az egészségturizmus jelenlegi keretrendszerét tudományos-technikai szempontból jogászok, egészségügyi szakemberek és sporttudományos szakemberek alakították ki. Így fordulhat eló, hogy a különféle szakterületek más jelentésú terminusokat alkottak. Mivel az egészségturizmusban több szakterület kívánta önállóan értelmezni a saját területével összefüggó fogalmakat, így önálló fogalmakat alkottak, esetleg idegen szavakból önálló szavakat képeztek le. Ez azért jelent problémát, mert a szolgáltatások igénybevevói az egészségturizmusban használt fogalmakat érthetố és alkalmazandó kommunikációs eszköznek tekintik.

A hazai egészségturizmus megújuló definíciójaként javasolt az egészségtudatos turizmus fogalmának bevezetése. Az egészségtudatos turisztikai kereslet a céltudatos és rendszeres testmozgással, a megfelelő táplálkozással, a minőségi pihenéssel és a szabadidô optimális kihasználásával érheti el jólléti céljait. Ez a fogalom abban tudna különbözni 
az egészségturizmus fogalmától, hogy nem igényelné a legalább 1 éjszaka vagy 24 óra eltöltését az adott desztinációban, hanem egy annál rövidebb időtartamot foglalna magába.

A jobb érthetôség érdekében már összeállításra került egy új ábrás elrendezés, amely letisztultan határozza meg a kapcsolódási pontokat (4. ábra). $\mathrm{Az}$ egészségturizmus hazai és nemzetközi szakirodalmának feldolgozása során figyelembe lettek véve azok az új tendenciák is, amelyek módosíthatják a meglévő fogalmakat. részletekbe menó megalkotása és elfogadása nagyban segítené a turizmusban tevékenykedók igazodását, és az elvárható színvonal megfelelő alsó és felső határának kialakítását. A wellness, a prevenció, a rehabilitáció, az életmódváltás, a terápia pont annyira alkotják a jövő újabb lehetőségeit, mint a biotechnológiai kezelések, a mesterséges intelligencia kutatások vagy az e-orvoslás. Az eddig felhalmozott eredmények és egyéb terminológiai kutatómunka során szerzett tapasztalatok szakszerú kiértékelését követően szükséges lenne az Országos

\section{A tudatos egészségturizmus ábrája a kapott eredmények tükrében}

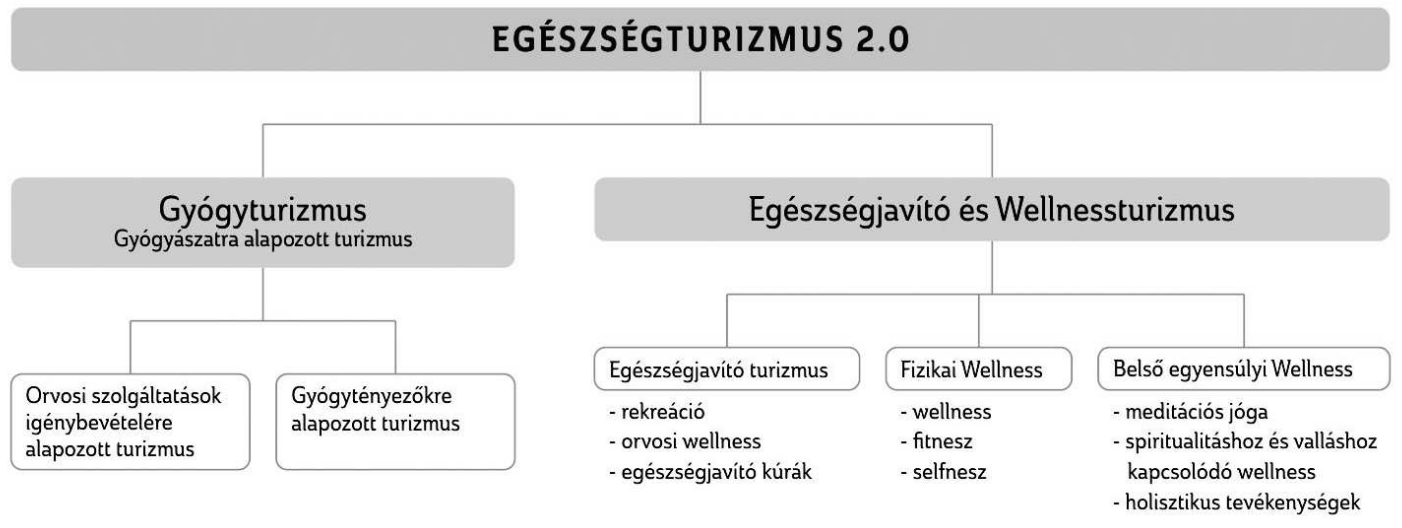

A hazai egészségturisztikai környezet döntően a belföldi egészségturisztikai szegmensben tud komolyan fejlódni, ami inkább a wellness turizmus területét fogja erősíteni. A wellness turizmusban az egészséges életmódhoz való egyéni hozzászokás hosszabb távon társadalmilag kedvező folyamatokhoz vezethet. Hazánkban a gyógyturizmusban rejlő lehetôségek túlnyomó része a hazai betegek OEP finanszírozással történő rehabilitációs, illetve prevenciós terápiás eljárásaihoz kapcsolható.

Az egészségturizmusban szükséges lenne egy terminológiai szabványosítás a különféle szakmai elvárások és tartalmak mentén, mert ahány résztvevője van a folyamatoknak, annyiféle módon értelmezhetô tartalommal használják ugyanazon fogalmakat. Sajnálatos módon ezeket az egységesító szándékokat egyes félrecélzott marketing kampányok vagy állami szakpolitikai csoportok érdekérvényesítése bármikor felülírhatja. Egy nemzetközi fogalomtárhoz való igazodás vagy egy sztenderdizált terminológiai rendszer nagyban hozzájárulna a hazai egészségturisztikai kínálat nemzetközi piacra való eljuttatásához.

A régóta idószerú, szakmai ismérveket is magában foglaló turizmus törvény ilyen terminológiai
Egészségturizmus Fejlesztési Stratégia pontosítása, amihez a digitalizáció és az infokommunikációs fejlódés okán ma már sokkal egyszerúbb, rövidebb és érthetőbb információátadásra lesz szükség.

\section{Felhasznált irodalom}

AQUAPROFIT (2007): Országos egészségturizmus fejlesztési stratégia. Aquaprofit Zrt., Budapest.

ARDELL, D. (1977): High Level Wellness: An Alternative to Doctors, Drugs, and Disease. Emmaus PA: Rodale Press.

BOOKMAN, M. Z. - BOOKMAN, K. R. (2007): Medical Tourism in Developing Countries. New York: Palgrave Macmillian.

CASSENS, M. - HÖRMANN, G. - TARNAI, C. - STOSIEK, N. - MEYER, W. (2012): Trend Gesundheitstourismus. Prävention und Gesundheitsförderung. 7(1). pp. 24-29.

FÓRIS Á. - BÉRCES E. (2006): A wellness terminológiája. Magyar Tudományos Akadémia Magyar Nyelvốr. 130(4). pp. 399-413.

FÓRIS Á. (2005): Hat terminológiai lecke. Lexikográfia és terminológia kézikönyvek 1. Lexikográfiai Kiadó, Pécs. pp. 60-62. 
FRIEDL, H. (2007): Wer braucht Wellness - und warum gerade jetzt? Zeitschrift für integrativen Turismus und Entwicklung. 4(6). pp. 6-10.

HERMES, K. (2005): Medical wellness. Wellnesskonzepte aus den USA in Deutschland. In: Rüdiger, M. (ed): Ökotropologische Forschungberichte. Schwarzenbeck: B. 7 Verlag. pp. 32-51.

HERTEL, L. (1992): Wellness und Gesundheitsförderung in den USA: Begriffsklärung, Entwicklungen und Realisierungenimbetrieblichen Bereich.Zeitschrift für Präventivmedizin und Gesundheitsförderung. Bielefeld: Die Gesellschaft. 4. pp. 36-48.

HORKAY N. (2003): Turisztikai márka és márkapolitika a desztináció-menedzsmentben, I. rész. Turizmus Bulletin. 7(1). pp. 47-53.

KIS Á. (2005): Terminusalkotás: a terminológiai helyzet és a terminológiai szerep. In: Dobos Cs. (szerk.): "Mindent fordítunk és mindenki fordít." Értékek teremtése és közvetítése a nyelvészetben. Bicske: Szak Kiadó. pp. 106-112.

MAGYAR TURIZMUS ZRT. (2008): Egészségturizmus szakmai háttéranyag. Magyar Turizmus Zrt., Budapest. https://docplayer. $\mathrm{hu}$ /18002534-Egeszsegturizmus-szakmai-hatteranyag.html Letöltve: 2018. január 20.

MICHALKÓ G. - RÁTZ T. (2011): Egészségturizmus és életminốség Magyarországon. Fejezetek az egészség, az utazás és a jó(l)lét magyarországi összefüggéseirôl. MTA Földrajztudományi Kutatóintézet, Budapest.

MICHALKÓ G. (2012): Turizmológia. Akadémiai Kiadó, Budapest.

MOLNÁR CS. (2011): Kelet-Magyarország egészségturisztikai pozíciója és a fürdőfejlesztések gazdasági hatásainak többszempontú vizsgálata. In: Juhász K. - Balázs J. (szerk.): Határok nélküli Tudomány: Kihívások és lehetôségek a tudományterületek határain: Innováció és TurizmusÍzelítô a Harsányi János Fôiskolán folyó kutatói munkákból. Tanulmánykötet. Harsányi János Fóiskola, Budapest. pp. 1-13.

NEMZETGAZDASÁGI MINISZTÉRIUM (NGM) (2010): Új Széchenyi Terv Vitairat. http://20102014.kormany.hu/download/b/14/10000/001_ Egeszsegipar.pdf Letöltve: 2018. január 18.

ROBBIN, Z. - BRAD, A. (2000): Reklám az interneten. Budapest: Geomédia Szakkönyvek.

RULLE, M. - BRITTNER, W. (2011): Gesundheitstourismus. München, Wien: Oldenburg. pp. 242-253.

SMITH, M. - PUCZKÓ L. (2010): Egészségturizmus: gyógyászat, wellness, holisztika. Akadémiai Kiadó, Budapest.

VASILEIOU,M.-TSARTAS,P.-STOGIANNIDOU, M. (2016): Wellness tourism: Integrating special interest tourism within the Greek tourism market. Tourismos. 11(3). pp. 210-226.

ZSARNÓCZKY M. (2015): Az egészségturizmus ellentmondásai. In: Futó Z. (szerk.): Tudomány és innováció a lokális és globális fejlódésért: nemzetközi tudományos konferencia elóadásai. Szent István Egyetem Egyetemi Kiadó, Szarvas. pp. 274-282.

ZSARNÓCZKY M. (2017a): Egészségturizmus történeti fejlődése Eszak-Magyarországon. In: Nagy Z. B. (szerk.): LIX. Georgikon Napok: A múlt mérföldkövei és a jövố kihivásai. Pannon Egyetem, Georgikon Kar, Keszthely. pp. 585-593.

ZSARNÖCZKY M. (2017b): Az egészségturizmus folyamatainak vizsgálata Észak-magyarországi mintaterületeken. Doktori (PhD) értekezés. Szent István Egyetem, Enyedi György Regionális Tudományok Doktori Iskola, Gödölló.

\section{Internetes források}

KINCSES GY. (2011): Az egészségturizmus korszerủ értelmezése. http://www.kincsesgyula.hu/dokumentumok/egtur/egeszegturizmus_2011_attekinto.pdf. Letöltve: 2018. január 20. 